vol. i, p. 94, means knowledge of fate. That stones were harbingers of good and bad luck is well known in Indian folk-lore. There may well have been some such stone, whether soap-stone or opal or some other, with which a "white" elephant's forehead could properly be compared.

I regret I have no copy of the commentary to refer to. Perhaps M. Léon Feer would give us Buddhaghosa's opinion on the point. But in face of Professor Windisch's very beautiful combination, it seemed desirable to point out at once the considerations which naturally occur to one on the other side.

I may add that the pole of a plough $(\bar{\imath} s \bar{a})$ is constantly used as a simile in descriptions of elephants. See Maha Vansa, x, 4. 7; Majjhima, i, 414; Vimāna Vatthu, xx, 8, and xliii, 9. M. Léon Feer, in his edition of the Samyutta (Pāli Text Society, 1884), has nangala-sĩsa a, but the correct reading is certainly nangalīs $\bar{a}$, as given in the note from $\mathrm{S}^{1}$ and $\mathrm{S}^{3}$.

T. W. RhYs Davids.

\title{
2. The Semitic Origin of the Old Indian Alphabet.
}

Sir,-It is, I believe, admitted that some of the modern alphabets of India, including, of course, the Deva-nāgarī, are more or less derived from the Southern or Maurya alphabet of the Asoka inscriptions. It will also be apparent, on a comparison of the inscriptions and documents of different periods, that the Sinhalese and the ancient Maldive as well as the Kawi alphabets are derived from the same Asoka alphabet. The question, therefore, of the Semitic origin of this Southern Asoka alphabet, first mooted by Professor Weber, and so ably discussed by Professor Bühler in his recent essay on the subject, ${ }^{1}$ is of general interest, irrespective of its great importance in palæographical researches. Besides, it is always a step in

1 In Sitzungsberichte der Kais. Akademie der Wissenschaften in Wien: Philosophisch-Historische Classe. Band exxxii. V. Indran Sludies, by George Bühler. No. 3: "On the Origin of the Indian Brähma Alphabet." 
advance to ascertain to what extent the ancient Indians were indebted for their culture to Semitic races.

Amongst the many weighty arguments adduced by Prof. Bühler in support of the Semitic theory, he attaches great importance to the one founded on the inscription on Sir Alexander Cunningham's Eran coin, now in the British Museum. It is, so far as I know, the only inscription in the Southern alphabet yet discovered in India which reads from right to left. $\mathrm{He}$ considers it "the link which was wanted in order to complete the chain of arguments proving the Semitic origin of the Brähma alphabet." 1

In reference to this point I may be permitted to draw Prof. Bühler's attention to the additional evidence which can be gathered from ancient Ceylon inscriptions, many scores of which passed under my observation when I was on the Archæological Survey. The oldest of them are cut in pure Brāhmì lipi, the Southern Asoka alphabet. The characters often vary in type, and are in several instances inscribed reversedly, whilst some inscriptions have been discovered which actually read from right to left. Two such inscriptions have been published with tentative transcripts and translations-one by $\mathrm{Mr}$. Bell in his valuable report on the Archæology of the Kegalle District, ${ }^{2}$ and the other by Mr. Parker in the Ceylon Literary Register. ${ }^{3} \mathrm{Mr}$. Bell, in discussing his inscription, mentions the existence of others like it in the Kegalle District. Mr. Parker, in his ingenious explanation of the "retroversion" of the letters in his inscription, says "it is the earliest instance of what is known in Ceylon as Peralibasa. It is impossible to exhibit the freaks of the carver in a bare transliteration. Some of the letters are reversed vertically, some laterally, while two syllables have the consonants transposed, and a few letters are correctly cut." 4

1 l.c., p. 3.

2 Ceylon Sessional Papers, xix, 1892, p. 69.

3 Vol. ii, p. 408.

4 I am indebted to Mr. D. W. Ferguson for drawing my attention to Mr. Parker's insoription. 
This, I submit, can hardly be the true solution of the question. Peralibasa is not the reversion of letters so as to be read backwards from right to left. It is a way of speaking jocularly in a language obtained by the transposition of two accented syllables in a given expression, which may consist of one or more words, ${ }^{1}$ as, for instance, Kolam̆ba yanavā ('I go to Colombo')=Yalan̆ba konavā. Ali baňdinavā ("to tether elephants')=Bali an̆dinavā. Polvatte dev-medura ("the church at Polwatta')=Valpotte mev-dedura, etc.

As I have said, these are but two inscriptions out of several that have been found inscribed reversedly. Mr. Bell has noted that the one he published in his archæological report already referred to was "not the sole instance even in the Kegalle District." This oft-repeated peculiarity of so many inscriptions certainly cannot, I submit, be merely accidental or due to the ignorance of the inscribers; the more so, because of the important fact that the anomaly is to be met with only in the most ancient inscriptions, in the Southern Asoka character. I am not aware of any of a later date which read from right to left, or in which individual letters are reversedly cut. It is, therefore, but reasonable to suppose that they point to a stage when the Brāhma letters were still under Semitic influence, and were written and read both from right to left and vice versa $\hat{a}-\mathbf{a}$ period earlier than that of Asoka's edicts, and possibly earlier even than that of the Eran coin, which Prof. Bühler assigns to a date "not very far distant from the middle of the third century B.c."

If, on closer inspection, the supposition I have put forward holds good, the inscriptions show the extent to which the art of writing had already spread in the third century B.c., and also go to corroborate the hitherto disputed statement in the Sinhalese annals regarding the intercourse between India and Ceylon before the introduction of

1 See Mr. Goonetilleke's interesting article in the "Orientalist" of Jan. 1884 (vol. i, pt. 1), pp. 5-12. 
Buddhism by Mahindo, the son of Asoka. ${ }^{1}$ In the absence of facsimiles, however, it is not possible to discuss the inscriptions in detail ; and I must, therefore, content myself for the present with calling attention to the new and valuable evidence which they seem to afford.

Let me conclude this note by mentioning the suggestion made to me by Prof. Rhys Davids, as to the possibility of the Indians having borrowed their Brăhma alphabet from the Sinhalese, who in turn may have got it from the Semitic people then trading in Ceylon, for Ceylon in those olden days is said to have been the centre of Eastern commerce. ${ }^{2}-$ Yours faithfully,

Don Martino de Zilva Wickremasinghe.

3. Mahuan's Account of Bengal.

Netherclay House, Taunton, Sept. 20th, 1895.

Dear Sir,-I beg to offer a few remarks on Mr. Phillips's interesting article in the July number of the Journal on Mahuan's account of Bengal.

Cheh-ti-gan. This corresponds precisely to Chittagong (Chatgánw). At that place a traveller proceeding to the interior would transfer himself from a sea-going vessel to a country boat to go up the Meghna, just as the Chinese pilgrim describes. The distance, 166 miles to Sonargáon, is also very nearly correct. Sonārgáon, however, is not "Suvarna-gramma, or Golden Town," but Suvarnakāragrāma, or Goldsmith's Village. The site is not unknown, as Mr. Phillips supposes. It is on the Meghna, about twelve miles east of Dacca. A very interesting account of the ruins and remains at this place by Dr. Wise will be found in the Bengal Asiatic Society's Journal, vol. xliii, p. 82.

1 See Mr. Parker's interesting Report on Archæological Diseoveries at Tissamahärāma (Journal Ceylon Branch of the Roy. As. Soc., vol. viii, pt. 1, pp. 70-75), where he has arrived at the same conclusions as I have done here.

2 See "Ceylon," by Sir James E. Tennent, vol. i, pp. 571, etc. (Ceylon as known to the Phoenicians). 